Discussion of which alternative is administratively preferable should not, however, be permitted to obscure the basic objections to the present sweeping disqualification. Either alternative is preferable to existing statutory provisions. The important consideration is that there is no reason from the point of view of social desirability to deny benefits to workers who are unemployed either because of the attempts of an employer to change the status quo by insistence on changed terms and conditions of work or because of his refusal to offer work except on conditions which are substandard or illegal. The issue is not whether strikes are "voluntary," or whether the payment of benefits would represent an award of "strike or lockout" benefits and thus place the state in an "unneutral" position, but whether statutory" provisions should be drafted to permit determinations to be made in the light of objective social policy without regard to the existence of a labor dispute. The answer seems clear. The statutory provision disqualifying workers unemployed as the result of a labor dispute should be amended to exclude from disqualification workers unemployed as the result of:

(1) a lockout,

(2) the failure or refusal of the employer to conform to the laws of the United States or the state pertaining to wages, hours or other conditions of work,

(3) the employer's insistence on wages, hours or other conditions of work less favorable than those prevailing for similar work in the locality, or

(4) a requirement that employees join a company union or resign from or refrain from joining any bona fide labor organization.

\title{
Employer Fault vs. General Welfare as the Basis of Unemployment Compensation
}

EARLE V. SIMRELL'

PERHAPs it should be taken for granted that the payment of unemployment compensation does not depend upon any employer's fault in causing unemployment. Yet even when this is recognized as a matter of law, there is evidence in judicial and administrative decisions of strong emotional resistance to such law. For example, a Wisconsin circuit court, after upholding an award of benefits to a woman worker whose last employer refused to reemploy her after childbirth, and who could find no other suitable work, expressed its regrets:

† Assistant General Counsel, Federal Security Agency. 
"This case is a vivid illustration of the working of the unemployment compensation act. It was no fault of the Folding Furniture Works that this employe became pregnant. Yet the employer is held liable. ...

"The employer was responsible for the unemployment only in the sense that he let her go and did not take her back. But when it is recognized that he had to fill her position while she was disabled, in order to get the work done, it can readily be understood why he would not take her back; because he did not need two employes to do the work of one, we assume; and if he took her back he would have to discharge the new employe and be liable for unemployment benefits to this new employe.

"Whichever employe the employer elected to employ when Mrs. Woyak sought work again, the employer was going to be forced to pay benefits. He was 'between the devil and the deep sea'. And that is just where the Wisconsin law places an employer who happens to get an employe who becomes sick for less than a year. The law is in the interest of the sick employe. It is hard on the employer." 1

It is a short step from a feeling that unemployment compensation regardless of employer fault may be law but is not justice to an interpretation of the law to deny compensation for unemployment if an employer contesting the claim is not at fault.

In Michigan a claimant had asked for a change of shift in order to be at home to care for her three-year-old child during the hours when she could get no one else to stay with the child. She was refused because her foreman thought so well of her work that he would not let her go. A circuit court found "that there was nothing to show that there was any obligation on the part of the employer to change shift for her," and disqualified her for having "left work voluntarily without good cause attributable to the employer." 2 The decisive effect given to the absence of any "obligation on the part of the employer" to make it possible for the claimant to care for her child and still keep her job was supported by the court's general understanding of the nature of the unemployment compensation law, expressed as follows:

". . . this act is an act to help the economic condition of the State and its people to alleviate suffering, embarrassment, and unrest caused by unemployment due to the fault or acts of the employer. If an employer refuses or fails to cooperate in stabilization of labor or employment he is penalized by being required to pay a larger per cent. of the amount of his payroll into the insurance fund. If

1. Folding Furniture Works, Inc. v. Industrial Comm., Wis. C. C., Dane Cy. Dec. 3, 1941, CCH Unemployment Ins. Serv.-Wis. I 1950.07. Unemployment compensation in all states is paid from state funds to which employers contribute.

2. Courney v. Unemployment Comp. Comm., Genesee Cy. (Mich.) C. C., March 15, 1945 (unreported) (emphasis supplied). 
on the other hand he does cooperate and assists in stabilization of labor, thereby reducing the unemployment of the head of the family, and so betters the economic condition of the people and State, he is rewarded by being required to only pay a lesser per cent. of the amount of his payroll into the insurance fund." 3

A failure "to cooperate in stabilization" might have been found in the foreman's refusal to attempt any adjustment, but, since the employer had not failed in any "obligation," the court saw the claimant's unemployment as outside the purposes of the unemployment compensation law.

If the feeling is conveyed to a legislature that "it is hard on the employer" if unemployment compensation is paid for unemployment for which he is not to blame, the result may be piecemeal amendment of the statute to compromise in some degree between the test of employer-fault and the basic purpose of alleviating the effects of unemployment in order to promote the general welfare. The Mest Virginia law was amended in 1943 to disqualify a worker who "left vork voluntarily without good cause, involving fault on the part of the employer." 4 This express injection of employer fault is rare, but a substantial number of legislatures have inserted such indefinite phrases as "attributable to the employer" to limit the "good cause" which will be recognized for a worker's voluntarily leaving a job.' Such amendments serve as vehicles for the sense of injustice of tribunals talking the employer-fault approach, even though in the light of the purpose of unemployment compensation laws to promote the public welfare a more reasonable interpretation would be independent of employer fault.

Two tendencies thus cooperate: (1) to subject contested issues of interpretation to a sense of injustice in the payment of benefits unless a previous employer is in some way to blame for the unemployment, and

3. The circuit court's general theory of the law is in contrast to the Michigan Supreme Court's view in Lawrence Baking Co. v. Unemployment Comp. Comm., 308 Mich. 198, 13 N. W. (2d) 260 (19.14), discussed later in this article. Claimants are apt to te in a poor position to carry appeals to a court of last resort. Consequently the law is often eettled for them in the lower courts.

4. West Virginia Unemployment Compensation Law, Art. VI, §4, as amended, W. VA. Code ANv. (Michie, Sublett \& Stedman, 1943) \$2366(78) (emphosis cupplicd), followed by amendment in 1941 of Section 5(a) of the Virginia unemployment compens3tion law.

5. Query whether even in these provisions fault is used in the sence of a breach of legal obligation. The word as used in statutory declarations of policy to provide compencation for workers "unemployed through no fault of their own" has been construed to mean cauces "subject to the employee's own volition." Huiet v. Schwob MIfg. Co., 196 Ga. 355, 27 S. E. (2d) 743 (1913). The concept of employer fault, as reflected, for example, in the two judicial statements quoted above, is never precisely defined in the decisions which crem to show its influence.

6. See Kempfer, Disqualification for Voluntary Lracing and XYisconduch, page 147 at page 150 supra. 
(2) to adopt piecemeal legislation more or less susceptible to such interpretation.

These twin tendencies have prompted the Chairman of the Social Security Board to describe as one of the "major weaknesses of existing State laws" that "The function of disqualifications is shifting from limiting benefits to workers unemployed through no fault of their own to limiting payments to cases where the employer is at fault." 7

\section{General Welfare as the Basis of Unemployment Compensation.}

Before experience rating, unemployment compensation laws were challenged as arbitrary for their failure to relate the burden of contributions to responsibility for causing unemployment. When the Alabama law was upheld by the United States Supreme Court, ${ }^{8}$ Justice Sutherland's dissent argued that due process was denied because " $a$ disproportionately heavy burden will be imposed by the tax upon those whose operations contribute least to the evils of unemployment, and, correspondingly, the burden will be lessened in respect of those whose operations contribute most." 9 "Let us suppose," he wrote, "that A, an employer of a thousand men, has retained all of his employees. B, an employer of a thousand men, has discharged half of his employees. The tax is upon the payroll of each. A, who has not discharged a single workman, is taxed upon his payroll twice as much as B, although the operation of B's establishment has contributed enormously to the evil of unemployment while that of A has contributed nothing at all." 10 Such a result the dissenters thought clearly unreasonable, but even the dissent argued only that each employer should bear the costs of unemployment resulting from his own operations, without reference to whether the employer was to blame for such unemployment or could have prevented it. ${ }^{11}$

The United States Supreme Court, however, held it to be no valid objection that "those who pay the tax may not have contributed to the unemployment. . . ." 12 The majority pointed out that "Nothing is more familiar in taxation than the imposition of a tax upon a class or upon individuals who enjoy no direct benefit from its expenditure, and who are not responsible for the condition to be remedied." 13

7. Letter of A. J. Altmeyer to War Mobilization Director Byrnes, June 2, 1944, reprinted in 90 Cong. Rec., Aug. 8, 1944, at 6841-2. See also George E. Bigge (Member, Social Security Board), Strength and Weakness of Our Unemployment Compensation Program in Chamber of Cossmerce of the U. S. A., Social Security in America (Addresseg, Nat. Conf. on Social Security, 1944) 24.

8. Carmichael v. Southern Coal \& Coke Co., 301 U. S. 495 (1937).

9. Id. at 527-8.

10. Id. at 528.

11. Id. at $530-1$.

12. Id. at 521 .

13. Id. at 521-2. 
This, which would be unquestioned as to taxes for general revenue, was regarded as no more objectionable when special taxes are levied for specific purposes. Common examples were cited, such as cigarette taxes and chain store taxes for schools, liquor taxes for old-age pensions, gasoline taxes, beer taxes, and cosmetics taxes for unemployment relief. "A corporation," Justice Stone noted, "cannot object to the use of the taxes which it pays for the maintenance of schools because it has no children." 14

The basis of the law, and the test of its ralidity, was held to be the public purpose of relieving unemployment. That unemployment compensation meets this test the United States Supreme Court, in accord with the courts of Alabama, Massachusetts, and New York, ${ }^{15}$ left no doubt:

"We need not labor the point that expenditures for the relief of the unemployed, conditioned on unemployment alone, without proof of indigence of recipients of the benefits, is a permissible use of state funds. For the past six years the nation, unhappily, has been placed in a position to learn at first hand the nature and extent of the problem of unemployment, and to appreciate its profound influence upon the public welfare. . . . The evils of the attendant social and economic wastage permeate the entire social structure. . . . When public evils ensue from individual misfortunes or needs, the legislature may strike at the evil at its source. If the purpose is legitimate because public, it will not be defeated because the execution of it involves payments to individuals." 10

The test of public purpose being met, employer contributions were viewed as a legitimate means of financing the social benefits of the legislation and, in general, of distributing its costs. "Since the [contributing employers] may not complain if the expenditure has no relation to the taxed class of which they are members, they obriously may not complain because the expenditure has some relation to that class, that those benefited are employees of those taxed; or because the legislature has adopted the expedient of spreading the burden of the tax to the consuming public by imposing it upon those who make and sell commodities." 17

\section{Legislative Policy and the Effect of Experience Rating.}

Has the system of variable tax rates, known as "experience rating," changed all this to require that the public purpose of alleviating the

14. Id. at 523.

15. Beeland Wholesale Co. v. Kaufman, 234 Ala. 249, 174 So. 516 (1937); Hores Brothers Co. v. Unemployment Comp. Comm., 296 Mass. 275, 5 N. E. (2d) 720 (1936); Chamberlin, Inc. v. Andrews, 271 N. Y. 1, 2 N. E. (2d) 22 (1936).

16. Carmichael v. Southern Coal \& Coke Co., 301 U. S. 495, 515, 516, 518 (1937).

17. Id. at $\mathbf{5 2 5 .}$ 
effects' of unemployment be limited by responsibility on the part of individual employers in causing it ${ }^{18}$ And, whether for constitutional reasons or otherwise, have state legislatures framed their unemployment compensation laws, with experience rating, to exclude unemployment for which a claimant's former employers are not to blame? The Supreme Courts of Michigan, Minnesota, and Wisconsin have rejected such limitations, in Minnesota and Wisconsin on issues of statutory construction, in Michigan on issues of both statutory construction and constitutionality. ${ }^{19}$

The first of the three decisions, in Boynton Cab Company v. Neubeck, came in Wisconsin, the Mt. Sinai of experience rating. A taxicab driver was discharged after having had three accidents during eight weeks of employment. The employer contended that he had been "discharged for misconduct connected with his employment" and therefore under the statute should be disqualified. ${ }^{20}$ Negligence in causing the accidents, and violation of the employer's rules in failing to report two of them and in failing to comply with the employer's standards of care, were alleged. The Commission found that the driver had been "partly responsible for the accidents" but awarded benefits in the conviction that mere negligence or minor violation of the employer's rules, without some wilful or wanton disregard of the employer's interests, did not constitute "misconduct" as the term was intended in the disqualification.

On appeal to the Supreme Court, the Commission emphasized the significance of the questions of legislative policy underlying the specific disqualification. In answer to the employer's justification for the discharge, the Commission interpreted the disqualification as having "nothing to do with the question of rightness or wrongness of the employer's act in discharging. He may be entirely justified, for example, in the case of an inefficient employee who is not worth retaining, without in any manner affecting the employee's right to benefits." 21 They reiterated this position more broadly:

"When an employee suing for damages for breach of contract prevails, he is recovering damages for the injury inflicted on him by his employer. In the field of unemployment compensation, eligi-

18. For the theories and methods of this system see Arnold, Experience Rating, pago 218 infre.

19. Lawrence Baking Co. v. Unemployment Comp. Comm., 308 Mich. 198, 13 N. W. (2d) 260 (19.44), cert. denied, 65 Sup. Ct. 43 (U. S. 1944); Fannon v. Federal Cartridge Corp., 18 N. W. (2d) 249 (Minn. 1945); Boynton Cab Co. v. Neubeck, 237 Wis. 249, 296 N. W. 630 (1941).

20. WIS. Stat. (Brossard, 1943) $\$ 108.04$ (4)(a) disqualifies for benefits a worker who "has been discharged by the employer for misconduct connected with his employment." On this disqualification in state laws generally see Kempfer, Disqualificalion for Voluntary Leaving and Misconduct, page 147 supra.

21. Brief of Industrial Comm., p. 40. 
bility for benefits is in no manner conditioned on the rightness or wrongness of the employer's severance of the employment relation, but contrarily is conditioned on whether the rights, which an employe has accrued during the course of his employment, and which would normally be available to him at the time of discharge, are to be considered as nullified by a penalty imposed out of public policy considerations." 22

The State Advisory Committee on Unemployment Compensation, representing employers and labor, and the Visconsin Manufacturers Association filed briefs as amici curiae supporting the argument of the Commission. ${ }^{23}$ All three briefs were clear and emphatic in arguing, not only the consistency of their construction with experience rating, but its downright necessity to the purposes of experience rating. Said the Commission, "'Experience rating' was certainly not designed for the purpose of allowing employers to restrict and sabotage the efficient operation of the primary purpose of any unemployment compensation law, namely, the payment of benefits to out-of-work employes. Nothing could strike the cause of experience rating a more grievous blow than to have it prostituted to this purpose." 24 The Advisory Committee urged that the employer's construction would be "flagrantly destructive" of the legislative purposes both in providing benefits and in providing an incentive to employers to regularize employment: $:^{53}$

". . . if mere inefficiency, lack of normal productivity, or trivial peccadillos discoverable in the case of a great many low-income employes, are 'misconduct,' then an employer can drastically reduce his working force, and equally augment the ranks of the unemployed, by laying off the relatively inefficient members of his force, because of their inefficiency, without cost to himself. His ability to do that would diminish just that much the incentive afforded by the operation of the law to regularize his employment and eliminate such lay-offs.

"It is no answer to the foregoing argument to say that it is hard on the employer to require him to pay unemployment compensation to an employe whom he was justified in firing because of inefficiency. Unemployment compensation is not a penalty imposed on the employer because of fault on his part, but rather is an involun-

22. Ibid.

23. The brief of the State Advisory Committee stated (p. 9) as positively as the Commission that the Commission and the court were not concerned with "the question of the employer's right to discharge, or of his moral or legal justification for co doing." It added, "The man last hired and first laid off is the ineficient fellow, the one who deas not pay a profit when business is poor, the one who is prone to malie mistalies. If compenstion is denied to him, because the employer selects him for discharge on account of those qualities, then the statute will defeat its own purpose, by withholding benefits from those who nead them most." Id. at 22.

24. Brief of Industrial Comm., pp. 18-9.

25. Brief of State Advisory Committee, pp. 20-8. 
tary contribution for the relief of unemployment attendant upon his operations." 26

The Wisconsin Supreme Court, in a strong opinion largely reflecting the briefs, affirmed the Commission's award of benefits, holding their interpretation of the "misconduct" provision to be essential to the "principal purpose and object under the act of alleviating the evils of unemployment." 27 Although the court did not discuss the relation of experience rating to the case, this factor obviously did not move it to modify its view.

In Michigan the same basic issue between public purpose in relieving unemployment and employer-fault in causing it was raised in Lavrence Baking Company v. Unemployment Compensation Commission, ${ }^{28}$ a case involving the labor dispute disqualification. ${ }^{29}$ The claimants, with other employees, had gone on strike. The employer's operations were interrupted for only about fifteen minutes. New employees were immediately hired and there was no further stoppage of the employer's operations although the strikers' union continued to picket the company plant. On the day after the strike began, the employer notified each striking employee by letter that he had been replaced by a new employee.

Since the Michigan labor dispute disqualification applies only to a claimant's weeks of unemployment "due to a stoppage of work existing because of a labor dispute in the establishment in which he is or was last employed," 30 the state agency awarded benefits for weeks of unemployment after the stoppage of the employer's operations had been ended by replacement of the striking employees. The employer contended that this was contrary to the language of the disqualification and the general declaration of legislative policy in enacting the unemployment compensation law; but the referee, the appeal board, the circuit court, and finally the state supreme court all held that the law (1) did not bar benefits for unemployment after the employer had replaced the strikers and resumed operations, and (2) did not contemplate any determination of the merits of the labor dispute. In both of these respects the decisions followed those of the supreme courts of $\mathrm{Ne}$ braska and North Carolina and the administrative interpretation which was already established both in Great Britain and in this country when the Michigan Legislature adopted the language in question. ${ }^{31}$

26. Id. at 26-7.

27. Boynton Cab Co. v. Neubeck, 237 Wis. 249, 258-9, 296 N. W. 636, 640 (1941).

28. 308 Mich. 198, 13 N. W. (2d) 260 (1944), cert. denied, 65 Sup. Ct. 43 (U. S. 1944).

29. On the general subject of this disqualification see Lesser, Labor Dispules and Unemployment Compensation, page 167 supra.

30. Michigan Unemployment Compensation Act $\$ 29(\mathrm{c})$, as amended; $12 \mathrm{Mrcr}$. STAT. ANN. (Supp. 1944) $§ 17.531$ (c) (emphasis supplied).

31. See Magner v. Kinney, 141 Neb. 122, 2 N. W. (2d) 689 (1942); In re Stcelman, 
Such a construction, the employer claimed, would make the statute unconstitutional "because it does not base disqualification for benefits upon a determination of the merits of the labor dispute resulting in unemployment, and because it imposes a penalty against the employer, which constitutes an interrention by the State in behalf of the employees in the labor dispute." 32 The state agency replied, "If appellant's arguments are correct then benefits may' not be paid in any case without adjudication that the employer has committed a wrongful act because all benefit payments are charged to an employer's experience record. Since none of the eligibility (Sec. 28) or disqualification (Sec. 29) provisions of the act are based upon a consideration of whether the employer has been at fault, the whole unemployment program would be unconstitutional." 33

The employer's argument, said the Court, "is based upon the premise that the payment of compensation to employees on strike is a penalty upon the employer, because its rate of contribution to the unemployment fund will thereby be increased." 34 The Court's answer to this premise was decisive, although the reasoning would bear amplification:

"The public purpose of the unemployment compensation law is to alleviate the distress of unemployment, and the payment of benefits is not conditioned upon the merits of the labor dispute causing unemployment. Likewise, the required contribution of the employer to the unemployment compensation fund is not determined upon the basis of the merits of the dispute. The increase in the amount of the employer's contribution to the fund because of its experience record of payments to employees is not in any sense a penalty. By the unemployment compensation act, the legislature provided a method of determining the employer's contribution to the compensation fund, and it did not see fit to base the amount of such contribution upon the merits of a labor dispute or upon the right or wrongdoing of the employer in connection with such dispute." 35

Actually the labor dispute disqualification in the Michigan law, as in most other state unemployment compensation laws, would deny benefits to strikers whose unemployment is due to a stoppage of work existing because of a labor dispute even though the dispute is solely the fault of the employer. On the supposed basis of a public policy of neutrality as between employer and labor engaged in a labor dispute, the provision

219 N. C. 306,13 S. E. (2d) 514 (1941). These decisions reviewed the prior administrative interpretations. The Michigan court criticizes the decision in Board of Review v. MidContinent Petroleum Corp., 193 Okla. 36, 141 P. (2d) 69 (1943) in which "stoppzge of work" was construed to refer to the individual worker's, not the employer's, operations.

32. As summarized by the court, 308 Mich. at 213,13 N. W. (2d) at 265 .

33. Reply brief for Commission-Appellee, p. 10.

34. 308 Mich. at 214,13 N. W. (2d) at 265.

35. Ibid. 
denies benefits in lockouts as well as strikes, and in cases where a labor dispute is due to the employer's violation of a legal contract or state or federal law. Whatever may be thought of the merits of such a policy of neutrality even when it means neutrality toward other policies of the state itself, it is clear that unemployment resulting from a labor dispute is not compensated on the basis of fault on the part of the employer. But a line must be drawn somewhere if individuals are not to be excluded indefinitely from the protection of the unemployment compensation law when unemployment originating in a labor dispute continues for other reasons, perhaps long after the labor dispute itself is over. The employer may permanently reduce his labor force, change its membership, or for other reasons no longer have work available for those who were involved in the dispute. Some laws draw the line where unemployment is found to be no longer "due to a labor dispute in active progress." But since the "active progress" of a labor dispute is something of uncertain nature and calling for highly subjective determination, most laws have attempted a more objective measure. By drawing the line where unemployment is no longer due to "a stoppage of work which exists because of a labor dispute," they have provided a rule of thumb which in general prevents the payment of compensation to workers involved in the dispute while the employer's operations are substantially affected, but ends the disqualification when unemployment ceases to be due to the tangible effects of the dispute and continues because of lack of available work. ${ }^{36}$.

A stoppage of work at one establishment may also be caused by a labor dispute at another, e.g., where a railroad strike causes a factory to shut down for lack of transportation. While the workers involved in the dispute will be denied benefits, those laid off at other establishments because of a secondary stoppage of production will be compensated although their employers are not to blame for their unemployment. ${ }^{37}$

Thus, the labor dispute provvision, both in denying compensation and in permitting it, is an apt illustration of the dependence of eligibility and disqualification upon the legislature's judgment of whether payment of unemployment compensation is in the interest of the general welfare rather than upon employer-fault in causing unemployment.

Moreover, under the Michigan law and most other unemployment compensation laws, the payment of compensation is reflected in the "experience" of those employers who employed the claimant in the past period of employment from which his benefit rights are derived. It is the so-called "base-period employer" whose contribution rate may be affected, whether or not he is the employer involved in the labor dispute-or, as in other cases, the employer from whom the claimant

36. See Lesser, Labor Dispntes and Unemployment Compensation, page 167 supra.

37. See ibid. 
has most recently been separated. If the striking employees of the Lawrence Baking Company had immediately secured other jobs, and subsequently been laid off for lack of work, compensation for such later unemployment might have been charged to the Lawrence Baking Company as a base-period employer. For all that appears in the case, compensation actually paid them over the company's protest may have been charged to other employers who had paid the claimants' baseperiod wages. ${ }^{33}$

The prevailing methods of relating compensation to the "experience" of individual employers thus accentuate the lack of any necessary implication of fault on their part in causing the unemployment reflected in their experience. Their contribution rates are measured by their experience with the risk of unemployment as it affects the workers whom they have employed, not by their responsibility for the risl's being realized in individual cases. ${ }^{39}$ It would be anomalous for experience rating, itself generally disregarding questions of employer fault, to make eligibility and disqualification for benefits depend upon employer fault. Variable rates to reflect relative risk and to provide an incentive to reduce risk do not imply a measurement of fault any more in Unemployment Compensation than in Trorlmen's Compensation, a program whose basic objective and very reason for being have been to provide compensation regardless of employer fault.

In Minnesota the conflict between employer fault and general welfare as guides to interpretation was recently brought to perhaps its most direct determination so far in the unemployment compensation program, in the case of Fannon o. Federal Cartridge Corporation." The claimant, who had previously been in good health, after working in an ordnance plant for about fourteen months collapsed and was sent to the hospital. Her doctor advised her that she "would not recover as long as she continued [at the plant]." She was incapacitated for about four months, during which time she was almost blind as the result of her past work. After her recovery she worked for two other employers until she was laid off because of a shortage of materials; she then registered for work and claimed unemployment compensation.

38. Michigan Unemployment Compensation Act \$20, 12 Mick. Srut. Axis. (Supp. 1941) § 17.521. See also Arnold, Experience Raling, page 218 ivfra, at 234-5.

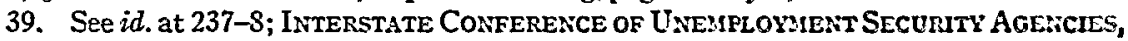

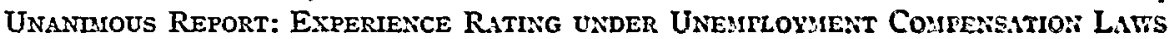
(1940) 40 , recommending that charges be made on the basis of having paid the claimant the wages entitling him to benefits, rather than having caused his unemployment:

"Does liability inhere in the act of discharging a worker who subsaquently" receives benefits, or in the payment of wages? If it is concluded that the act of discharge itself is not an equitable method of assessing liability-and this esems a logical conclusion-then it follows that liability inheres primarily in the payment of wages."

40. 18 N. W. (2d) 249 (Minn. 1945). 
The state unemployment compensation agency decided, after a hearing, that the claimant had not discontinued her employment at the ordnance plant "voluntarily and without good cause attributable to the employer," and awarded benefits. ${ }^{41}$ The ordnance company appealed, contending (1) that, since the claimant had left its employ without action by the company, her leaving was voluntary, and (2) that her leaving was "without good cause attributable to the employer," which, according to the company's argument, must mean "some unreasonable conduct on the part of the employer which causes the employee to resign." ${ }^{42}$ Both of these contentions were related to the experience rating provisions of the unemployment compensation law on the theory that payment of benefits to one in the claimant's circumstances was precluded by the purpose of experience rating to encourage employers to stabilize employment. ${ }^{43}$

The Minnesota Supreme Court looked to the legislative declaration of policy ${ }^{44}$ and concluded that "There is nothing in this language to justify the conclusion that benefits under the act accrue only when unemployment is the result of some wrongful act or fault of an employer." 45 The effect of benefit payments upon employers' experience rating was recognized, but not as altering the avowed legislative purpose to promote the general welfare by providing benefits to those who are unemployed through no fault of their own. The court decisively rejected the fallacy that because experience rating makes it to the interest of an employer to maintain stable employment whenever possible, the payment of benefits is limited to cases where unemployment is due to the employer's fault. It proceeded then to decide against the em-

41. Minn. Laws 1943 , c. $650, \S 5$ (A), amending 1 MinN. Srat. (1941) $\$ 268.09$ provides that an individual shall be disqualified for benefits "If such individual voluntarily and without good cause attributable to the employer discontinued his employment by such employer and all wage credit earned in such employment shall be cancelled." On this disqualification in general see Kempfer, Disqualification for Voluntary Leaving and Misconduct, page 147 supra.

42. Brief of Relator, Minn. Sup. Ct., p. 24.

43. Id. at $15-7$.

44. 1 MinN. STAT. (1941) $§ 268.03$ : "As a guide to the interpretation and application of sections 268.03 to 268.24 , the public policy of this state is declared to be as follows: Economic insecurity due to unemployment is a serious menace to the health, morals, and welfaro of the people of this state. Involuntary unemployment is therefore a subject of general interest and concern which requires appropriate action by the legislature to prevent its spread and to lighten its burdens. This can be provided by encouraging employers to provide more stable employment and by the systematic accumulation of funds during periods of employment to provide benefits for periods of unemployment, thus maintaining purchasing power and limiting the serious social consequences of poor relief assistance. The legislature, therefore, declares that in its considered judgment the public good and the general welfare of the citizens of this state will be promoted by providing, under the police powers of the state for the compulsory setting aside of unemployment reserves to be used for the benefit of persons unemployed through no fault of their own.

45. $18 \mathrm{~N}$. W. (2d) at 252 (emphasis the court's). 
ployer on each issue, in a way which indicates rather strongly the contrast in effect between the general-welfare approach and the employer-fault approach:

(1) Whether the claimant left her employment "voluntarily" was decided by whether "continuance thereof would endanger her health and personal welfare." The test is not whether the employer or the worker acted to terminate the employment but whether the termination, if the worker's act, was "an act of necessity." 40 ". . . where, as here, an employe is impelled because of sickness and disease to terminate employment because continuance thereof would endanger his health and personal welfare, such termination is an involuntary rather than a voluntary act on the part of the employe" even though the employer has also submitted involuntarily to the termination."

If a leaving is involuntary, there is no disqualification whether the cause is attributable to the employer or not. The court approves an Attorney General's opinion which made the distinction quite clear. "As I view it," the Attorney General had written, "voluntarily quitting' means discontinuing the employment because the employee no longer desires to remain in the relationship of an employee with the employer from whom he has separated"; therefore, he concluded, an employee compelled to separate from his employment by a force beyond his control could not be said to have left roluntarily even though the cause for the discontinuance was found to be not attributable to the employer. ${ }^{4 s}$ Although there is uncertainty due to the overlapping of the two issues in the Fannon case, a fair inference from the Court's own opinion and its approval of the Attorney General's is that faced with "an act of necessity" from causes wholly unconnected with a claimant's employment the Court would find that the claimant had not left voluntarily and was therefore not subject to the disqualification. Circumstances of less compelling force than necessary to make the leaving involuntary, however, may still be good cause for leaving and if "attributable to the employer" then preclude disqualification.

(2) Whether the claimant had "good cause attributable to the employer" was held to be independent of the test of whether there was "any wrongful act, negligence, or failure on the part of the employer." A worker's leaving may be for "good cause attributable to the employer," the court emphasized, "even though the employer be free from all negligence or wrongdoing in connection therewith." It is a question of relation, rather than responsibility for sins of either omis-

46. Room is left for distinctions of degree between serious impairment of health and relatively minor discomforts and unhealthful effects. "Necessity" is a matter of degree.

$47.18 \mathrm{~N}$. W. (2d) at 252.

48. Opinion of the Att'y Gen., No. 151, Oct. 12, 1943, CCH Unemployment Ins. Sarv. -Minn. I 1975.06. 
sion or commission. "Facturs or circumstances directly connected with employment" are attributable to the employer. ${ }^{49}$

Affirmative standards for determining good cause for leaving work were drawn from the statutory provision for determining whether an unemployed individual has refused suitable work. ${ }^{50}$ "Under this section, a claimant cannot be disqualified for refusing to accept employment which may be a risk to or endanger his health. If this be true, then certainly it is unreasonable to hold that a claimant must lose credits or be denied benefits where he has been compelled to terminate employment because such employment has resulted in a physical condition or disease likewise dangerous to health and personal safety." "61 These standards clearly represent interests of the worker which are deemed worthy of legislative protection, rather than conditions of employment for which an employer is held affirmatively responsible. ${ }^{62}$ Some of them overlap to greater or less extent obligations imposed on employers by law. For example, an employer may be bound to take certain measures of safety. Still he has no general obligation to prevent risks to his workers' health. Work may be unsuitable by these standards without any implication of failure on the part of the employer to meet legal or any other standards of conduct. What is to be expected of workers, not what is required of employers, is the general standard by which claimants are to be awarded or denied benefits.

As these standards of "suitable work" are clearly related to the individual, testing what is suitable for him, measuring risk to his health and safety, it is evident that it is the effect upon the individual claimant, not the effect of the same circumstances upon other workers, which is decisive. The court referred to the claimant's allergy to gunpowder

49. 18 N. W. (2d) at 252.

The phrase "attributable to the employer," so construed, still limits the adequacy of the remedy for involuntary unemployment. It may deny benefits to individuals whose current unemployment is solely due to lack of suitable work, simply because a past separation was for reasons which though good reasons were not related to the employment. Compare the recommendation of the Councri. of State Governasents, UNEMPloyment Coupensation In the Post-War Period (1944) 1, that "Each state should re-examine its statutory provisions governing disqualifications to be certain that the penalties imposed do not restrict the right of an individual to change his work for good personal or family reasons."

50. 1 MinN. Stat. (1941) $\S 268.09$ (4)(a), (b) provides that "In determining whether or not any work is suitable for an individual, the director shall consider the degree of risk involved to his health, safety, and morals, his physical fitness and prior training, his expcrience and prior earnings, his length of unemployment and prospects of securing local work in his customary occupation, and the distance of the available work from his residence," and further provides that "no work shall be deemed suitable" under certain conditions. See Menard, Refusal of Suitable Work, page 134 supra, on the general subject of standards of suitable work.

51. $18 \mathrm{~N}$. W. (2d) at 252 (emphasis the court's).

52. See Menard, Refusal of Suitable Work, page 134 supra. 
and apparently understood that this contributed to her illness. The fact that other workers might not suffer similar effects was considered immaterial. The language of the disqualification for voluntary leaving is specific in saying "without good cause attributable to the employer." It is not a test of proximate cause to determine responsibility but a test of whether good cause attributable to the employer contributed to the claimant's leaving, regardless of what other causes may also have contributed.

An amendment to the Minnesota law, adopted in 1943,63 cancelling wage credits for an individual who "cannot accept his former employment when offered by such employer for reasons not attributable to such employer or if he is unable to perform such work," gave the employer another argument for disqualification. This is the type of amendment in unemployment compensation laws which results from legislative compromise between the fundamental public purpose of the law to alleviate the effects of unemployment and the concept of unemployment compensation as a penalty upon employers for causing unemployment. Despite the literal effect of the language of the provision, however, the court refused to believe that the legislature intended "to subject an individual to physical risk or disease in connection with his employment in order to remain qualified for benefits," while carefully safeguarding unemployed claimants generally against being forced by threat of disqualification to accept unsuitable work. It concluded, therefore, that disqualification for failure to accept former employment was meant to apply only when such employment was suitable for the claimant.

If unemployment compensation were a penalty upon a claimant's former employer for failing to keep the claimant employed, there would of course be a logical distinction between the refusal of former employment and the refusal of a job with another employer. But the risk to the individual's health and safety is obviously the same, and from the point of view of the State's purpose to promote the general welfare of its citizens, the court's interpretation is clearly in harmony with the unemployment compensation law as a whole. Orthodox rules of construction support the court in looking to the legislative intent in the entire act, in presuming that the legislature did not intend an unreasonable result, and in maintaining the effect of the original suitable work provisions against an implied amendment. ${ }^{54}$ An unemployment compensation law is so definitely an organic whole that there is special justification for not permitting the basic plan of the program to be impaired by piecemeal amendments unless the legislature makes it

53. Minn. Laws 1943 , c. 650, \$ 5(7)[G], amending 1 Minz. Srat. (1911) §263.09. Minn. Stat. (MIason, Supp. 1944) $\$ 4337-27(7)[G]$.

54. 2 Sutherland, Statutory Construction (3d ed. 1943) $\$ \$ 4703,4706 ; 1 \mathrm{id}$. at $\S \S 1934,1935$. 
entirely clear that it intends such a result. Where the legislature adds an odd fixture to the edifice it is in the best traditions of the judicial function to incorporate the addition with the least possible conflict with the architecture of the whole. Still it is an uncertain and unsatisfactory business to rely on hard interpretations to mitigate bad amendments. In this instance the legislature proceeded to confirm the court's judgment of the legislative purpose by repealing the amendment. ${ }^{\text {bi }}$

\section{The Two Approaches Contrasted.}

The Supreme Courts of Wisconsin, Michigan, and Minnesota, all of them states with employer contributions as the means of financing the entire costs of compensation and all with experience rating, have thus rejected employer fault as a test of compensable unemployment. They have made it plain that a public program to alleviate the economic and social consequences of unemployment, plus a method of financing by means of taxes on employment, plus a system of variable rates reflecting past experience with the risk of unemployment rather than fault in causing unemployment, do not add up to make a system of employer liability for fault.

But the ghost of employer fault as a test of compensability has haunted the unemployment compensation program as it previously haunted workmen's compensation. ${ }^{56}$ No court of last resort has established it, with any definiteness or consistency, as legal doctrine. Its effect has been rather as a subversive influence, hard to isolate and positively identify as an element of decision, yet apparently diverting courts and administrative tribunals occasionally from the purpose of the unemployment compensation laws to protect the general welfare from the effects of involuntary unemployment. ${ }^{57}$ Sometimes the concept seems to be used as a test of actual breach of legal obligation, more often as an undefined standard of responsibility. ${ }^{58}$ In spite of the con-

55. Minn. Laws 1945 , c. 376, effective July 1, 1945.

56. See, e.g., Samuel Bertram Horovitz, Injury and Deatir Under Workmen's Compensation LAws (1944) 99-108 on the variety of injuries incurred at work for which the defense to compensation has been an "act of God."

57. For discussion of the use and abuse of the term "involuntary unemployment" ace Harrison, Statutory Purpose and "Involuntary Unemployment," page 117 supra.

58. See the cases cited hereafter to illustrate the employer-fault approach to specific issues of eligibility and disqualification. $C f$., e.g., the language of the Michigan circuit court quoted at the beginning of this article ["there was nothing to show that there was any obligation on the part of the employer to change shift for her"] with the decision of the South Dakota court in Morrell \& Co. v. Unemployment Comp. Comm., 13 N. W. (2d) 498 (S. D. 1944), disqualifying a worker who sought reemployment after childbirth on the theory that benefits were intended only for those "unemployed because of the failure of industry to provide employment." Since even so the claimant would have been entitled to benefits, being currently unemployed only for lack of a job, the court's premise scems to have been that her previous employer was not responsible for her previous loss of her job; therefore no benefits. 
cept's lack of substance as legal doctrine, there is a vital difference in analysis and results between decisions reached from the point of view of a former employer as an adversary party," measuring his responsibility for a claimant's unemployment, and decisions reached from the point of view of the general welfare, testing whether the unemployment for which compensation is claimed is excluded for reasons of public policy from the benefits of the law.

If the issue is whether the claimant is "available for work," the employer-fault approach is to interpret "work" as meaning the particular work the claimant "has been doing," as if he were claiming damages for breach of an employment contract, and to deny benefits if through no fault of the employer the claimant cannot continue in his former work, even though he has the best of reasons and is ready and willing to take other, suitable work. A mother who is admittedly available for work between 7:00 in the morning and 12:00 at night is held "unavailable for work" because in order to care for her children she must discontinue a job on the midnight shift; $;^{\circ 0}$ although a worker who will not accept her employer's change in her work hours from a fiveday week on a day shift to a six-day week on the night shift is held available for work because the employer, in changing hours, has made the working conditions unsuitable for her. ${ }^{11}$ A worker who leaves because of colds attributed to a drafty workplace is held unavailable, with the comment,

"At this day and age there is statutory provision for supervision

59. This is related to the tendency to thinl: of unemployment compensation claims as claims against an employer rather than upon a public trust fund for unemployed workers, with the result "that contests regarding the payment of benefits are considered to be batween the worker and his employer, with the State administrator only a bystander." See address by Chairman Altmeyer of Social Security Board in Interstate Confrerence of Eurnoyarent Security Agencies, Proceedings of Seventh Annual Meetrag (1943) 60. And see Stevens v. Minnesota Division of Employment and Security, 207 Minn. 420, 431, 291 N. W. 890,891 (1940): "It is plain that the [unemployment compensation] ast does not impose any duty or obligation upon [employer] in favor of [claimant]. It is only against the special fund, created by this legislation, that [claimant] may assart any claim for unemployment compensation. The only duty this law lays upon the employer is to pay the proper amount to the fund." Courts have emphasized the necessity of administrative initiative and responsibility in establishing rights to unemployment compensation, rather than um. piring contests between employers and claimants. See, e.g., Hagadone v. Kirlipatricls and Unemployment Comp. Division, 15! P. (2d) 181 (Idaho 1941); and see Silverstone, The Administration of Unemployment Compensation, page 205 infra.

60. Judson Mills v. Unemployment Comp. Comm., 204 S. C. 37, 28 S. E. (2d) 535 (1914). See also Altman and Lewis, Limited Arailability for Shaft Employmont: A Critcrion of Eligibility for Unemployment Compensation (1944) 22 N. C. L. REv. 189 and (1944) 28 MinN. L. REv. 387.

61. Iee v. Spartan Mills, S. C. Ct. of C. P., Spartanburs Cy., April 3, 1944, CCH Unemployment Ins. Serv.-S. C. If 3123, applying the decision of the South Carolina Supreme Court in Judson Mills v. Unemployment Comp. Comm., 204 S. C. 37, 28 S. E. (2d) 535 (1944). 
of work shops. The superintendent has authority to see that they are properly heated and ventilated and other normal working conditions provided for. This would not mean that every work shop must be so regulated as to meet anything more than normal conditions and situations." 62

But the general-welfare approach is to interpret "work" as meaning suitable work and test the claimant's availability by his attachment to the labor market and his readiness and willingness to work, rather than his readiness to continue in his last job. ${ }^{63}$ The employer-fault approach, in requiring availability for the work he has been doing, will disregard injury to the worker's health, ${ }^{64}$ family obligations, ${ }^{66}$ or any other circumstance for which the former employer is not responsible. ${ }^{60}$ The general-welfare approach, while recognizing that unemployment compensation is limited to those who are ready, willing and able to work, ${ }^{67}$ will not require continuance in a particular job in disregard of

62. Brown-Brockmeyer Co. v. Board of Rev., 70 Ohio App. 370, 378, 45 N. E. (2d) 152, 156 (1942).

63. See, e.g., Faulkenberry v. Dep't of Industrial Relations, Ala. C. C., Madison Cy., March 21, 1944, CCH Unemployment Ins. Serv.-Ala. If 8127, Ben. Ser. 8657-Ala. 'Ct. D. (V7-8); Carani v. Danaher, Conn. Super. Ct., Hartford Cy., Oct. 18, 1943, CCH Unemployment Ins. Serv.-Conn. T 8132, Ben. Ser. 8416-Conn. Ct. D (V7-3); see also Henry v. Ford Motor Co., 291 Mich. 535, 289 N. W. 244 (1939). Among administrative decisions see Ben. Ser. 2692-Ore. A (V3-2); Ben. Ser. 8963-Ill. R. (V7-12); Ben. Ser. 8852-Pa. R (V7-10). And see Freeman, Able to Work and Available for Work, page 123 supra, on the general subject.

The requirement was adopted from the British Unemployment Insurance Act and its previously established meaning might therefore be presumed to have been intended by the state legislatures. Magner v. Kinney, 141 Neb. 122, 2 N. W. (2d) 689 (1942). The British decisions had consistently tested availability in relation to the labor market generally rather than the claimants' previous work. See Social Security BosRd, Benerit Decisions of the British Uarpire (Ben. Ser., Gen. Supp. No. 1, 1938). These decisions were apparently not considered by the Ohio and South Carolina courts in the cases cited supra notes 60 and 62.

64. Brown-Brockmeyer Co. v. Board of Rev., 70 Ohio App. 370, 45 N. E. (2d) 152 (1942); Stevens v. Selby Shoe Co., Ohio Ct. App., Scioto Cy., Jan. 15, 1945, CCH Unemployment Ins. Serv.-Ohio \ 8163.

65. Judson Mills v. Unemployment Comp. Comm., 204 S. C. 37, 28 S. E. (2d) 535 (1944); Huiet v. Schwob Mfg. Co., 196 Ga. 855, 27 S. E. (2d) 743 (1943) (a wife who "chooses between continuing employment and living with her husband" in a new locality, though available for work there, "waives her status as an insured employee.")

66. Carwood Mfg. Co. v. Huiet, Ga. Super. Ct., Barrow Cy., June 5, 1943, CCH Unemployment Ins. Serv.-Ga. If 1950.06 (worker whose transportation to previous job had failed held unavailable for work since there was no "duty on the employer . . . to furnish such means of transportation"; whether claimant was available for other work not considered.)

67. Availability for a particular job is not necessary to prevent unemployment compensation being used as "sick benefits," since availability for other gainful work is required. See Labor and Industry Dep't v. Unemployment Comp. Bd. of Rev., Pa. Super. Ct., Jan. 27, 1944, CCH Unemployment Ins. Serv.-Pa. I 8096, correcting this misconception in its early opinion in Labor and Industry Dep't v. Unemployment Comp. Bd. of Rev., 133 Pa. 
the state's interest in the health and safety of its citizens and in the maintenance of family life.

If the issue is whether the claimant has been "discharged for misconduct connected with his worls" the employer-fault approach is to look to whether the employer was justified in discharging him, while the general-welfare approach is concerned less with employer conduct than with the need of alleviating the effects of unemployment among those discharged for reasons not inconsistent with their being bona fide workers involuntarily out of work. ${ }^{63}$

If the issue is whether the claimant has left work voluntarily without good cause, the employer-fault approach tends to assume that either employer or worker must be held responsible for any separation so that any leaving without action by the employer must be a voluntary leaving. ${ }^{69}$ The general-welfare approach, not assuming that one or the other must be held responsible, will recognize that a worker may quit because he has to as well as because he wants to; voluntary leaving is understood not as a legislative redundancy but as distinct from a leaving which is "an act of necessity." 70 In deciding whether there was "good cause" for a worker's voluntary leaving, the employer-fault approach is first to read "good cause" as meaning "good cause attributable to the employer," when not so limited in the statute, on the premise that the limitation is implicit in the general policy of the law. ${ }^{71}$ With "attributable to the employer" in the statute either by enactment or

Super. 518, 3 A. (2d) 211 (1938). And see Fellela v. Unemployment Comp. Bd., R. I. Supar. Ct., Nov. 3, 1943, CCH Unemployment Ins. Serv.-R. I. \& 8039, holding that no benefits under the Rhode Island Cash Sickness Compensation Act (the only such state law now in effect) can be paid to one who is able to perform services for wages though unable to do his regular work. With such a disability compensation law, the "previous job" test of availability for work under the unemployment compensation lavy would leave such claimants stranded between the two programs.

68. Perhaps in part due to the leading decision of the Wisconsin court in Boynton Cab Co. v. Neubeck, discussed above, the employer-fault approach, though often argued, has been less evident in the decisions in these cases than in others. But gre Ben. Ser. 8101-La. A (V6-S) (claimant disqualified for discharge because of absence due to reliance on a carpool and failure to arrange other transportation); Ben. Ser. 8276-Tenn. A (V'G-12) (disqualified for discharge because of failure to use the diligence of a reasonably prudent man); and see discussion of general subject in Kempler, Disqualificat:on for Volumbry Leasing and Arisconduct, page 147 supra.

69. Labor and Industry Dep't v. Unemployment Comp. Bd. of Rev., 133 Pa. Supar. 518,3 A. (2d) 211 (1938) (leaving on doctor's advice held voluntary resardless of necesity to preserve health. "He was not discharged, dismissed or laid off by his employer"; therefore he quit voluntarily).

70. Fannon v. Federal Cartridge Corp., 18 N. IW. (2d) 249 (Minn. 1945), dicsussed in the text above. See also Kempfer, Disqualification for Voluntary Leacing ond Miscondust, page 117, supra, at 155 .

71. Morrell \& Co. v. Unemployment Comp. Comm., 13 N. W. (2d) 498 (S. D. 1914); and see Kempfer, Disqualification for Volnthtary Leasing and Mfiscondud, page 147 suffe, at 157 . 
by interpretation, the employer-fault approach is to determine whether any wrongful act, negligence, or breach of obligation on the part of the employer was responsible for the claimant's leaving. But the generalwelfare approach is to read "good cause" without limitation, if so the legislature wrote it, and to recognize as good cause any facts which made a claimant's voluntary leaving reasonable conduct in the circumstances. ${ }^{72}$. If the statute itself says "good cause attributable to the employer," the test is whether facts connected with either the employer personally or the employment, regardless of fault, contributed to the claimant's leaving and made his leaving reasonable in the circumstances; the claimant will not be disqualified for leaving work which is unsuitable by legislative tests prescribed in the interest of the general welfare, even though the employer is not to blame for the work's being unsuitable. ${ }^{73}$

If the issue is whether the claimant, in not accepting reemployment, has refused an offer of suitable work without good cause, the employerfault approach may look only to circumstances for which the employer is responsible to determine the suitability of the work or the claimant's good cause for refusing it. ${ }^{74}$ The general-welfare approach, on the other hand, will look to all the circumstances of the offered work in relation to the claimant, in order to determine the reasonableness of the claimant's refusal, rather than the employer's responsibility. ${ }^{76}$

To some extent decisions which seem to illustrate the employer-fault approach might be explained as the result of statutory details rather

72. Id. at 158 .

73. Fannon v. Federal Cartridge Corp., 18 N. W. (2d) 249 (Minn. 1945).

74. United States Coal \& Coke Co. v. Board of Rev., W. Va. C. C., Kanawha Cy., April 3, 1943, CCH Unemployment Ins. Serv.-W. Va., I 1965.022; Feuchtenberger Bakeries, Inc. v. Board of Rev., W. Va. C. C., Kanawha Cy., April 15, 1943, ibid. (both cases of refusal to return to jobs in West Virginia after moving to another state; distance held immaterial since claimant had moved). Cf. Matter of Weymouth, W. Va. C. C., 13th Judicial Cir., March 26, 1943, CCH Unemployment Ins. Serv.-W. Va. I 1965.012 (claimant, whose employer refused to let her go back to work after two days absence, of which she had given advance notice without objection from the employer, refused similar work at other stores of the same company six and twelve miles away; whether claimant "should or should not" have refused on account of transportation difficulties and home duties "presents a close question . . . which would never have arisen had she not been dismissed." Held, no disqualification in view of circumstances of dismissal and fact that new offer was made months later when claimant applied for benefits).

75. Fannon v. Federal Cartridge Corp., 18 N. W. (2d) 249 (Minn. 1945); Forrest Park Sanitarium v. Miller, 233 Iowa 1341, 11 N. W. (2d) 582 (1943); Ben. Ser. 8085-N. J. R (VG8) (former laundry worker who left to take a defense training course and refused to return to her old job held not to have refused suitable work without good cause in view of her new slill and prospects for a better job in war industry); Ben. Ser. 8447-Mass. A (V7-3) (claimant who refused former job because of constant friction with foreman during previous employment held to have good cause for refusal, without determining the merits of the "friction"). See generally Menard, Refusal of Suitable Work, page 134 supra. 
than any general concept of the unemployment compensation law as a whole. Thus, the Ohio court, in requiring availability for the work the claimant had been doing, despite its injurious effects, implied that a different interpretation would have been reached if the legislature in prescribing what work might be refused without disqualification had used a standard of "suitable work," as other states did, instead of specifying certain conditions without relating them to any such general standard. ${ }^{76}$ But, by and large, such statutory variations seem less controlling than the tribunal's sense of the basic policy of the unemployment compensation law. A Massachusetts court, with a statutory disqualification for voluntary leaving "without good cause attributable to the employing unit or its agent," held that a leaving because of working hours injurious to the claimant's health was not voluntary," but the South Dakota court, with a statute recognizing "good cause" for leaving, unlimited by any reference to the employer, disqualified for leaving because of risk to the claimant's health during pregnancy. ${ }^{33}$ And the Iowa Commission, with "good cause" unlimited in the statute, disqualified a worker for leaving on account of injurious working conditions $;^{79}$ three years later with apparently a more-liberal view of the purpose of the law but with the statute amended meanwhile to recognize only "good cause attributable to his employer," the Commission held working conditions to be attributable to the employer regardless of fault and refused to disqualify a worker who left because they were injurious to his health, even though the employer had taken "every" precaution" to correct them. ${ }^{80}$ Such decisions as those of the Ohio and South Carolina courts construing availability for work as availability for the claimant's previous job, and that of the South Dakota court on voluntary leaving without good cause, are all justified in the opinions by the general policy of the law more than by any specific statutory language. ${ }^{81}$ The explanation of the employer-fault approach seems to lie deeper than in statutory details, in a concept of unemployment compensation as a liability imposed on the individual employer for causing the unemployment of individual workers, and a sense of injustice if the liability is imposed for unemployment due to no fault of the employer. It is the objection made at the beginning of the unemployment compensation program - and rejected by the United States Supreme Court

76. Brown-Brockmeyer Co. v. Board of Rev., 70 Ohio App. 370, 45 N. E. (2d) 152 (1942).

77. Mitchell v. Division of Unemployment Comp. (1943), Ben. Ser. S074-Mass. Ct. $\mathrm{D}(\mathrm{V} 6-7)$.

78. Morrell \& Co. v. Unemployment Comp. Comm., 13 N. W. (2d) 493 (S. D. 1914).

79. Unpublished decision, 1939, No. 39 C-49.

80. Ben. Ser. 7819-Iowa R (VG-2).

S1. Brown-Brockmeyer Co. v. Board of Rev., 70 Ohio App. 370,45 N. E. (2d) 152 (1912); Judson Mills v. Unemployment Comp. 204 S. C. 37, 28 S. E. (2d) 535 (1942); Morrell \& Co. v. Unemployment Comp. Comm., 13 N. W. (2d) 498 (S. D. 1944). 
- that "those who pay the tax may not have contributed to the unemployment," ${ }^{82}$ or going even further, that although their operations may have contributed to the unemployment they were not to blame..$^{83}$

\section{Conclusion.}

Since hardly any unemployment would be found to be due to a breach of legal obligation on the part of a former employer, the theory of employer fault applied in that sense as a test of compensability would substantially eliminate unemployment compensation. Taken in a looser sense, the argument of employer fault is that, especially with experience rating, the employer is unfairly "penalized" if benefits are paid for unemployment due to circumstances beyond his control. Yet unemployment following an ordinary lay-off of workers by an employer for lack of work is compensated without any question of how blameless, or even helpless, the employer may have been. Wartime restrictions, termination of war contracts, or ordinary business hazards may make his action unavoidable, but it makes no difference in the determination of his former workers' rights to unemployment compensation. ${ }^{84}$ The voluntary quit of a customer may be no more the fault of an employer than the voluntary quit of a worker; ${ }^{85}$ its effect in causing unemployment and an unfavorable rating of the employer's experience may be much greater. Yet no one, presumably, would now question the payment of benefits for unemployment resulting from the customer's voluntary quit, nor their being counted as part of the employer's experience with the risk of unemployment.

82. Carmichael v. Southern Coal \& Coke Co., 301 U. S. 495, 521 (1937).

83. As in Fannon v. Federal Cartridge Corp., 18 N. W. (2d) 249, (Minn. 1945) where compensation was contested because the claimant's separation from the appellant-employer, though due to working conditions, was not due to "unreasonable conduct" on the employer's part.

84. ". . . Unemployment in the plant of one employer may be due to competition with another, within or without the state, whose factory is running to capacity; or to tariffs, inventions, changes in fashions or in market or business conditions, for which no employer is responsible, but which may stimulate the business of one and impair or even destroy that of another. Many believe that the responsibility for the business cycle, the chief cause of unemployment, cannot be apportioned to individual employers in accordance with their employment experience; that a business may be least responsible for the depression from which it suffers the most." Carmichael v. Southern Coal \& Coke Co., 301 U. S. 495, 524 (1937).

85. If experience rating is thought of as an incentive to positive effort to reduce unemployment (see Burns, Unemployment Compensation and Socio-Economic Objectives, page 1 supra) it might be especially applicable to such problems of personnel management. The individual employer may be able to do more to reduce voluntary quits and discharges for misconduct than to reduce unemployment due to more remote and impersonal cconomic causes. See, e.g., Elton Mayo, The Human Problems of an Industrial Civilization (1933); Elton Mayo and George F. F. Losibard, Teamwork and Labor Turnover in THE AIRCRAFT INDUSTRY of Southern CaliforNia (Harvard School of Business Administration, Business Research Studies No. 32, 1944); numerous articles in Faclory Afatragemont and Maintenance and in The Personnel Journal; and the popularization of technical studies in Stuart Chase, Men at Work (1945). 
And we find the Wisconsin Advisory Committee on Unemployment Compensation, representing employers as well as labor, and the IVisconsin Manufacturers Association, joining the State Industrial Commission in persuading the Supreme Court of Wisconsin that unemployment compensation has no relation to a claim against an employer for fault on his part, that eligibility and disqualification are based solely on considerations of public policy, and that, to quote again language too emphatic for paraphrase, "nothing could strike the cause of experience rating a more grievous blow than to have it prostituted to this purpose" of "allowing employers to restrict and sabotage the efficient operation of the primary purpose of any unemployment compensation law, namely, the payment of benefits to out-of-work employees," Es

Experiments and studies in the direction of guaranteed annual wages show a promise of accomplishment, where circumstances permit, in the assumption by employers of contractual responsibility for stable employment. ${ }^{87}$ But the purpose of unemployment compensation is both less and greater than that. In the words of President Johnston of the United States Chamber of Commerce, "Benefit payments are only halfrations." the fault of a past employer, the measure of compensation should certainly be the amount of the worker's loss. As it is, the unemployed worker and his family still bear most of the loss directly, and the public at large bears it indirectly through the social consequences of lowered standards of living, loss of purchasing power, and often the burden of supplementary relief. ${ }^{59}$ On the other hand, the purpose of unemployment compensation laws goes beyond instability of the job a worker has, to include unemployment due to the job a worker cannot find. To quote Mr. Johnston further, it is necessary to "encourage mobility, flexibility, adaptation and retraining in order to absorb more continuously and promptly all of our labor power." 20 The employer-fault concept, tying the worker to his past job, is incompatible with such purposes.

Unquestionably the purpose of the unemployment compensation laws to serve the general welfare does not call for indiscriminate payments to the unemployed. Eligibility conditions and disqualifications

86. See page 187 supra.

87. See Jack Chernich and George C. Hellickson, Guaruiteed Arisual Whacs (1945); Elliclson, Labor's Demand for Real Employment Sceurily, page 253 infra; Murrar, The Guaranteed ANnual WAge (1945) and references thercin.

88. Chamber of Cominerce of the U.S. A., Social Security in Aurerica (Addrezses, Nat. Conf. on Social Security, 1911) 5.

89. Employer contributions are themselves largely a cost passed on to consumers, and to workers both as consumers and wage-earners. See HARRY A. MInLIS Arid Royal E. Montgonery, Labor's Rises and Sochal Insuratice (1938) 181.

90. Chamber of Commerce of the U.S. A., Sochl Security in Aurnuci (Addrezes, Nat. Conf. on Social Security, 1941) 6. 
serve their purpose in limiting the risks of the program. But what the Supreme Courts of Wisconsin, Michigan, and Minnesota have made clear is that such a purpose is one of public policy in the use of public funds for insurance against the social and economic consequences of unemployment, independent of the blamelessness of a previous employer for causing the unemployment. 